\title{
Evidence of secondary consumption of fish by double-crested cormorants
}

\author{
B. F. Blackwell, J. A. Sinclair \\ Maine Cooperative Fish \& Wildlife Research Unit, University of Maine, 5755 Nutting Hall, Orono, Maine 04469-5755, USA
}

\begin{abstract}
In 1993, we analyzed 742 regurgitant samples of nestling double-crested cormorants Phalacrocorax auritus from 10 colonies in Penobscot Bay, Maine, USA. A total of 21 species of fish were identified from otoliths. Further, we recovered 15 fish stomachs from regurgitant samples 14 of which contained otoliths. We compared lengths of otoliths for a given taxon represented in both regurgitants and fish stomachs recovered from regurgitants, and found no significant difference. We concluded that otoliths occurring in regurgitant samples can result from secondary consumption (i.e. the consumption of a prey fish containing otoliths in its stomach). Further, we caution that the use of otoliths in diet analyses of double-crested cormorants can inflate estimates of species percent occurrence and number.
\end{abstract}

KEY WORDS: Secondary consumption - Cormorants · Regurgitants - Otoliths

\section{INTRODUCTION}

The value of a prey species to a predator is dependent upon nutritional needs, foraging locations, prey abundance and vulnerability, and differential digestion of prey (Hyslop 1980, Duffy \& Jackson 1986, Furness 1990). Typically, the analysis of diets of marine mammals and seabirds requires the identification of species through the examination of partially digested remains, especially hard components such as otoliths of fishes. Researchers have been cautioned concerning the use of otoliths in estimation of prey size, number, and percent occurrence (Hyslop 1980, Duffy \& Jackson 1986, Jobling \& Breiby 1986, Harris \& Wanless 1991, 1993, Bowen et al. 1993). However, the implications, relative to data analyses, of otoliths or other hard remains occurring in faeces, pellet, regurgitant, or stomach samples as a result of secondary consumption (i.e. the consumption of predatory fish and the stomach contents of the fish) by marine mammals or seabirds (Perrin et al. 1973. Beach et al. 1981, 1982, Mead et al. 1982, Zonfrillo 1986) have not been specified. Here, we report evidence linking otoliths recovered from regurgitants of nestling double-crested cormorants to the prey of predatory fish and discuss the significance of secondary prey consumption to diet analyses based on otoliths.

\section{METHODS}

We collected regurgitants of nestlings in colonies located on 10 coastal islands in Penobscot Bay, Maine, USA $\left(44^{\circ} 01.0^{\prime}\right.$ to $44^{\circ} 22.7^{\prime} \mathrm{N}, 68^{\circ} 45.9^{\prime}$ to $69^{\circ} 02.5^{\prime} \mathrm{W}$ ). These islands range from 1 to 4 ha, with nesting substrate composed of grass, forbs, shrubs, and rock (Korschgen 1979). We visited colonies during the day during the first and second week of July, when nestlings were ca 2 wk old, and again during the last 2 weeks of July 1993.

Nestlings regurgitate readily when approached, thus we consider our samples representative of nestling rather than adult diets. We preserved regurgitants in $80 \%$ ethanol while in the field. Samples were stored below $0^{\circ} \mathrm{C}$ prior to analysis.

To identify prey remains, we used several sources (Gosner 1978, Robins et al. 1986, Scott \& Scott 1988, Page \& Burr 1991). In addition, we built a reference collection of fish, scales, vertebrae, and otoliths. We determined taxa of otoliths using a dissecting microscope, an otolith identification guide (Brodeur 1979), and our reference collection. All items identifiable as individuals or parts of individuals were segregated into major taxa. We removed any scales or skeletal remains immediately visible. After the initial discovery of a par- 
tially digested fish stomach lined with otoliths, we dissected any stomach found in a regurgitant, as well as the stomachs of any intact piscivorous fish. The remaining contents were flushed with water through 1.00 and $0.10 \mathrm{~mm}$ strainers. We then collected additional scales and skeletal remains for species identification.

We measured otolith lengths using vernier calipers. No otoliths that were broken or exhibited extreme abrasion were measured. Because our objectives did not include the use of otoliths in regressions of length of prey on otolith length, lengths were not measured in all samples. We tested the null hypothesis that mean otolith length for otoliths of a given taxon recovered from regurgitants does not differ from those of the same taxon recovered from fish stomachs taken from regurgitants. Otoliths recovered from the same regurgitant or the same fish stomach are not independent. Thus, within each regurgitant, we calculated the average length of those otoliths of a given taxon that were not found within the stomach of a fish. Likewise, we calculated the average length for otoliths of the same taxon recovered from a fish stomach. Our data were not distributed nor-

mally, so we used the nonparametric Wilcoxon 2sample test with normal approximation (SAS 1988) and a critical region of $\alpha=0.05$ for comparisons of otolith length means. However, because the Wilcoxon 2-sample test is of low power, the probability of a Type II error is high. Thus, to utilize a more powerful test, we wrote a FORTRAN program that randomly selected 5 otolith length means of a respective taxon and category (i.e. from regurgitant or fish stomach), calculated the average of the means, then repeated the process for an additional 99 random permutations. We tested the resulting data sets for normality and homogeneity of variances, then compared otolith length means using a $t$-statistic with a critical region of $\alpha=0.05$ (SAS 1988).

\section{RESULTS}

We collected 742 regurgitants from which we identified 35 species of fish and 8 species of invertebrates. A total of 197 of the regurgitants contained otoliths that could be identified at least to family (Table 1). Twentyone species were identified from otoliths, with species of hake (offshore Merluccius albidus, longfin Urophy- cis chesteri, and unidentified, i.e. otoliths not identifiable to species) occurring in $62.9 \%$ of the regurgitants containing 1 or more otoliths (Table 1).

Further, from regurgitants we recovered 15 fish stomachs, 14 of which contained otoliths and 1 which contained an intact prey fish (Table 2). Twelve of the fish were benthic species (sculpins Myoxocephalus spp., cunner Tautogolabrus adspersus, and wrymouth Cryptacanthodes maculatus) that are seasonal residents of shallow, subtidal and intertidal habitats in the Gulf of Maine (Tyler 1971, Moring 1990, Ojeda \& Dearborn 1990). Food items in the remaining 3 stomachs were not identifiable to family or species.

Otoliths recovered from fish stomachs represented 3 known taxa and unidentified hake (Table 2). The mean of the average lengths for hake otoliths recovered from 14 fish stomachs $(0.42 \mathrm{~cm}$; total of 50 otoliths measured) was not different $(Z=-0.8543, p>$ $|Z|=0.3930$ ) from that of otoliths from 90 regurgitants $(0.43 \mathrm{~cm}$; total of 490 otoliths measured). Further, our comparison of otolith length means from the randomization process indicated no significant difference between hake otoliths from fish stomachs and those from regurgitants $(\mathrm{n}=100, t=0.3011$, df $=98, \mathrm{p}>|t|=$ $0.7640)$. 
Table 2. Phalacrocorax auritus. Piscivorous fish, recovered from regurgitants collected from nestling double-crested cormorants on 10 colonies in Penobscot Bay, Maine, USA, during July 1993, that contained otoliths in their stomachs

\begin{tabular}{lcl}
$\begin{array}{l}\text { Species of fish } \\
\text { recovered }\end{array}$ & $\begin{array}{c}\text { Stomachs with } \\
\text { otoliths }\end{array}$ & $\begin{array}{l}\text { Taxa of otoliths } \\
\text { recovered }\end{array}$ \\
\hline $\begin{array}{l}\text { Cunner } \\
\text { Sculpina }\end{array}$ & 1 & $\begin{array}{l}\text { Unidentified hake } \\
\text { Offshore hake }\end{array}$ \\
Unidentified & 9 & $\begin{array}{l}\text { Sculpin } \\
\text { Atlantic tomcod } \\
\text { Unidentified hake }\end{array}$ \\
Wrymouth & 1 & Unidentified hake \\
aExcluding 1 stomach containing intact round herring
\end{tabular}

Likewise, the mean of the lengths for 10 sculpin otoliths recovered from the 1 fish stomach in which we found sculpin otoliths $(0.28 \mathrm{~cm})$ did not differ $(Z=$ $-1.6254, p>|Z|=0.104$ ) from the mean of the average lengths of sculpin otoliths recovered from 63 regurgitants $(0.41 \mathrm{~cm}$ i total of 145 otoliths measured). Our attempts to produce a normally distributed data set through randomization (i.e. using 100 to 200 random permutations) were not successful, although a normal distribution is theoretically possible as the number of random permutations approach infinity (Conover 1980). However, we chose not to continue the randomization process with the sculpin data, relying instead on our results from the nonparametric Wilcoxon 2-sample test.

Three of the taxa recovered from fish stomachs (sculpin, round herring Etrumeus teres, and Atlantic tomcod Microgadus tomcod) were represented also by otoliths and other physical remains in regurgitants. Similarly, all other species represented by otoliths in regurgitants, but not recovered from fish stomachs, were present as other remains. We recovered no evidence of hake species, other than otoliths, from the 742 regurgitants.

\section{DISCUSSION}

The analysis of a food sample from a cormorant often entails teasing apart a mass of well digested prey and indigestible remains (such as otoliths). The presence of otoliths, however, does not necessarily confirm that a species was preyed upon by cormorants. Otoliths recovered from a cormorant regurgitant might represent feeding by the cormorant's prey. Our initial recovery of otoliths from a fish stomach was fortuitous, in that the stomach was found separated from the body, partially digested, and open. The same taxon of otolith (in this case unidentified hake) was recovered from the stomach and throughout the regurgitant. We have demonstrated, through a comparison of lengths of otoliths for a given taxon represented in both regurgitants and fish stomachs, that there is overlap in size of prey taken by cormorants and predatory fish. Moreover, the possibility exits that a species, well represented by otoliths in regurgitants, occurs solely as a result of secondary consumption. For example, while hake species occurred in $62.9 \%$ of regurgitants that contained otoliths, no other physical remains of hake species were recovered from 742 regurgitants. Although we cannot confirm that cormorants did not prey upon hake species, the lack of physical remains, other than otoliths, is strongly supportive of secondary consumption.

Although secondary consumption of prey by marine mammals and seabirds has been recognized (Perrin et al. 1973, Beach et al. 1981, 1982, Mead et al. 1982, Zonfrillo 1986), no consideration has been given as to how information from secondarily consumed otoliths might affect one's results and conclusions. For example, in their investigation of pellets of Cape cormorants Phalacrocorax capensis as indicators of diet, Duffy \& Laurenson (1983) support the use of otoliths but recognize limitations when additional diet (i.e. stomach or regurgitant samples) and foraging ecology data are not considered. However, secondary consumption of otoliths is not discussed. Jobling \& Breiby (1986) state that the identification and counting of otoliths recovered from stomach or regurgitant samples can provide a quantitative estimate of prey species numbers. Such estimates are questionable if some or all otoliths are consumed secondarily. Thus, whether diet analyses are conducted for descriptive purposes or to quantify predation on fisheries (Milton \& Austin-Smith 1983, Birt et al. 1987, Craven \& Lev 1987, Kennedy \& Greer 1988, Milton et al. 1988, Hobson et al. 1989, Campo et al. 1993, Karwowski et al. 1994), we urge caution in the inclusion of otolith data. Further, we suggest detailed examinations of the stomachs of piscivorous fish and any separated fish stomachs recovered from regurgitant or stomach samples. Should otoliths be recovered from the stomachs of prey fish, consideration must be given to differentiating between predation by the cormorant and its prey, or excluding otolith data.

Acknowledgements. Our research was part of a larger study of the ecology of double-crested cormorants with funding provided by the U.S. Fish and Wildlife Service to the Maine Cooperative Fish and Wildlife Research Unit (MCFWRU) through Cooperative Agreement Number 14-16-0009-1557. Research Work Order Number 26. The Maine Unit is supported by the USDI National Biological Service, University of Maine (UM), Maine Department of Inland Fisheries and Wildlife (MDIFW), and the Wildife Management Institute. 
We offer special thanks for logistical support to R. B. Allen MDIFW, and P. Farr, Maine Department of Conservation: assistance in identifying prey species to the late $\mathrm{H}$. H. Dewitt, UM, and H. C. Perkins and D. A. Libby, Maine Department of Marine Resources; field and laboratory assistance to the participating students and staff of the University of Maine; programming assistance to $W$. B. Persons and $M$. T. Jones, UM. Finally, we thank W. B. Krohn and J. R. Moring, MCFWRU, and the 3 anonymous reviewers for their comments on this manuscript.

\section{LITERATURE CITED}

Beach RJ, Geiger AC, Jeffries SJ, Treacy SD (1981) Marine mammal - fishery interactions on the Columbia River and adjacent waters, 1981. 2nd Annual Report November 1, 1980-November 1, 1981. NWAFC Processed Report 82-04. NOAA National Marine Fisheries Service, Northwest and Alaska Fisheries Center, National Marine Mammal Laboratory, Seattle, WA

Beach RJ, Geiger AC, Jeffries SJ. Treacy SD (1982) Marine mammal - fishery interactions on the Columbia River and adjacent waters, 1980-1982. 3rd Annual Report to the NWAFC, March 1, 1980-October 31, 1982. NOAA National Marine Fisheries Service, Northwest and Alaska Fisheries Center, National Marine Mammal Laboratory, Seattle, WA

Birt VL, Birt TP, Goulet D, Cairns DK, Montevecchi WA (1987) Ashmole's halo: direct evidence for prey depletion by a seabird. Mar Ecol Prog Ser 40:205-208

Bowen WD, Lawson JW, Beck B (1993) Seasonal and geographic variation in the species composition and size of prey consumed by grey seals (Halichoerus grypus) on the Scotian shelf. Can J Fish Aquat Sci 50:1768-1778

Brodeur RD (1979) Guide to otoliths of some Northwest Atlantic fishes. National Marine Fisheries Service, Northeast Fisheries Center, Woods Hole Laboratory, Laboratory Reference No 79-36, Woods Hole, MA

Campo JJ, Thompson BC, Barron JC, Telfair II RC, Durocher P. Gutreuter S (1993) Diet of double-crested cormorants wintering in Texas. J Field Ornithol 64:135-144

Conover WJ (1980) Practical nonparametric statistics, 2nd edn. John Wiley \& Sons, New York

Craven SR, Lev E (1987) Double-crested cormorants in the Apostle Islands, Wisconsin, USA: population trends, food habits, and fishery depredations. Colonial Waterbirds 10 : $64-71$

Duffy DC, Jackson S (1986) Diet studies of seabirds: a review of methods. Colonial Waterbirds 9:1-17

Duffy DC, Laurenson LJB (1983) Pellets of Cape cormorants as indicators of diet. Condor 85:305-307

Furness RW (1990) A preliminary assessment of the quantities of Shetland sandeels taken by seabirds, seals, predatory fish and the industnal fishery in 1981-83. Ibis 132: 205-217

Gosner KL (1978) A field gusde to the Atlantic seashore from the Bay of Fundy to Cape Hatteras. The Peterson field guide series, Vol 24. Houghton Mifflin Company, Boston

Harris MP. Wanless S (1.991) The importance of the lesser sandeel Ammodytes marinus in the diet of the shag Phalacrocorax aristotelis. Ornis Scand 22:375-382

This article was submitted to the editor
Harris MP, Wanless S (1993) The diet of shags Phalacrocorax aristotelis during the chick-rearing period assessed by three methods. Bird Study 40:135-130

Hobson KA, Knapton RW, Lysack W (1989) Population, diet and reproductive success of double-crested cormorants breeding on Lake Winnipegosis, Manitoba, in 1987. Colonial Waterbirds 12:191-197

Hyslop EJ (1980) Stomach content analysis: a review of methods and their application. J Fish Biol 17:411-429

Jobling M, Breiby A (1986) The use and abuse of fish otoliths in studies of feeding habits of marine piscivores. Sarsia 71: $265-274$

Karwowski K, Hickey JT, Stilwell D (1994) Food study of the double-crested cormorant, Little Galloo Island, Lake Ontario, New York, 1992. US Fish \& Wildlife Service, New York Field Office, Cortland

Kennedy GJA, Greer JE (1988) Predation by cormorants, Phalacrocorax carbo (L.), on the salmonid populations of an Irish river. Aquacult Fish Mgmt 19:159-170

Korschgen CE (1979) Coastal waterbird colonies: Maine. US Fish \& Wildlife Service, Biological Services Program, FWS/OBS-79-09, Washington, DC

Mead JG, Walker WA, Houck WJ (1982) Biological observations on Mesoplodon carlhubbsi (Cetacea: Ziphiidae). Smithsonian Contr Zool 344

Milton GR, Austin-Smith PJ (1983) Population levels and the relationships of double-crested cormorants (Phalacrocorax auritus) and Great cormorants (Phalacrocorax carbo) to the sport and inshore commercial fisheries of Nova Scotia, 1979-1980. Wildlife Conservation Division, Nova Scotia Department of Lands and Forests, Kentville

Milton GR, Austin-Smith PJ, Dickie GE (1988) An examination of the diet of double-crested cormorants (Phalacrocorax auritus) foraging in coastal and inland waters. Wildlife Division, Nova Scotia Department of Lands and Forests, Kentville

Moring JR (1990) Seasonal absence of fishes in tidepools of a boreal environment (Maine, USA). Hydrobiologia 194: $163-168$

Ojeda FP, Dearborn JH (1990) Diversity abundance, and spatial distribution of fishes and crustaceans in the rocky subtidal zone of the gulf of Maine. Fish Bull US 88: $403-410$

Page LM, Burr BM (1991) A field guide to freshwater fishes, North America, north of Mexico. The Peterson field guide series. Houghton Mifflin Company, Boston

Perrin WF, Warner RR, Fiscus CH, Holts DB (1973) Stomach contents of porpoise, Stenella spp., and yellowfin tuna, Thunnus albacares, in mixed-species aggregations. Fish Bull US $71(4): 1077-1092$

Robins CR, Ray GC, Douglas J (1986) A field guide to Atlantic coast fishes, North America. The Peterson field guide series. Houghton Mifflin Company, Boston

SAS (1988) SAS/STAT User's Guide, Release 6.03 edn. SAS Institute Inc, Cary, NC

Scott WB, Scott MG (1988) Atlantic fishes of Canada. Canadian Bulletin of Fisheries and Aquatic Sciences No. 219. University of Toronto Press, Toronto

Tyler AV (1971) Periodic and resident components in communities of Atlantic fishes. J Fish Res Bd Can 28:935-946

Zonfrillo B (1986) Diet of Bulwer's Petrel Bulweria bulwerii in the Madeiran Archipelago. Ibis 128:570-572

Manuscript first received: September 29, 1994

Revised version accepted: February 2, 1995 